\title{
41. POROSITY VARIATION AND CONSOLIDATION ON THE NORTHEASTERN AUSTRALIAN MARGIN ${ }^{1}$
}

\author{
John Ladd, ${ }^{2}$ Kate Moran, ${ }^{3}$ Dick Kroon, ${ }^{4}$ Richard Jarrard, ${ }^{5}$ Min-Pen Chen, ${ }^{6}$ \\ Amanda Palmer-Julson, ${ }^{7}$ and Craig Glenn ${ }^{8}$
}

\begin{abstract}
Most of the sediments at Sites 819 through 821 are underconsolidated, likely the result of high sedimentation rates. Normally consolidated sediments appear at intervals of low sedimentation rate at Site 820. Overconsolidation occurs in the shallowest unit of Site 820, suggesting recent mass wasting, and at the deepest interval, which may define an older erosional surface.

At Site 819 for the depth range of 0 to $400 \mathrm{~m}$, porosity is correlated with percentage of mud and is inversely proportional to carbonate content.

Mass accumulation rates in the upper $30 \mathrm{~m}$ above a major hiatus at Site 819 are fairly constant from 240 to $100 \mathrm{k}$.y., following a 50-k.y. period of slightly higher accumulation rates. The mass accumulation rate increases steadily from $100 \mathrm{k} . \mathrm{y}$. to the present.
\end{abstract}

\section{INTRODUCTION}

The Shipboard Science Party (1991a, 1991b, 1991c) established that, to a first approximation, the porosity at Sites 819 through 821 on the continental slope off Grafton Passage followed the general pattern of normal consolidation with depth (Athy, 1930), that is, to a first approximation, the porosity decreased exponentially with depth. However, many local variations from this general trend were seen that, at least in some instances, seemed to correlate with variations in other physical properties. Here, we explore the controlling mechanisms of the porosity-depth functions for these three sites off northeastern Australia. The mechanisms that control sediment porosity include compaction history, compositional parameters (magnetic susceptibility, $\mathrm{CaCO}_{3}$ content, and grain size distribution), and mass accumulation rates. Compaction history is determined from the results of one-dimensional consolidation testing of selected wholeround samples from different lithologic units, compositional parameters are examined using statistical correlation techniques, and mass accumulation rates as a function of age are computed directly with compaction-corrected porosity. For a summary of the geology of the region and a location map of Sites 819 through 821 , see McKenzie and Davies (this volume).

\section{METHODS}

One-dimensional consolidation tests were performed on wholeround samples collected from Sites 819,820 , and 821 . The tests were run in incrementally loaded, back-pressured consolidometers. A load increment ratio of 2 was used. Each load increment was applied until the end of primary consolidation was achieved. The square-root of

\footnotetext{
${ }^{1}$ McKenzie, J.A., Davies, P.J., Palmer-Julson, A., et al., 1993. Proc. ODP, Sci. Results, 133: College Station, TX (Ocean Drilling Program).

${ }^{2}$ Lamont-Doherty Geological Observatory, Palisades, NY 10964, U.S.A.

${ }^{3}$ Atlantic Geoscience Centre, Bedford Institute of Oceanography, Dartmouth, Nova Scotia B2Y 4A2, Canada.

${ }^{4}$ Grant Institute of Geology, University of Edinburgh, West Mains Road, Edinburgh, EH9 3JW, United Kingdom.

${ }_{5}^{5}$ Department of Geology and Geophysics, University of Utáh, Salt Lake City, UT 84112-1183, U.S.A

${ }^{6}$ Institute of Oceanography, National Taiwan University, P.O. Box 23-13, Taipei 10764, Taiwan, Republic of China.

7016 Viceroy, Bryan, TX 77802 , U.S.A.

${ }^{8}$ School of Ocean and Earth Science and Technology, University of Hawaii, 1000 Pope Road, Marine Science Building 205, Honolulu, HI 96822, U.S.A.
}

time method (Taylor, 1948) was used to determine the end of primary consolidation.

Correlations have been made between porosity and three other parameters: magnetic susceptibility, $\mathrm{CaCO}_{3}$ content, and grain size. Two different porosity logs were used for these correlations: index porosity and composite porosity. Index porosity was determined from the shipboard measurement of index properties on discrete core samples (Shipboard Science Party, 1991). Index porosity was corrected for elastic rebound of the sediment using the rebound coefficient determined from consolidation tests. Composite porosity is a combination of porosity determined from cores using the gamma-ray attenuation technique (GRAPE, Shipboard Science Party, 1991) and porosity calculated from the lithodensity $\log$ (Jarrard, Jackson, et al., this volume). Magnetic susceptibility was measured with the shipboard multisensor track using a Bartington meter; $\mathrm{CaCO}_{3}$ content and grain size are from Kroon, Alexander, and Thompson (this volume).

Correlation coefficients $(C)$ were calculated as follows:

$$
C=\frac{\Sigma X(z) Y(z)}{\left[\Sigma X^{2}(z) \Sigma Y^{2}(z)\right]^{1 / 2}}
$$

where $X(z)$ and $Y(z)$ are quantities measured at depths $z$. Scientists have long known that porosity varies with depth below seafloor because of sediment consolidation. To determine the correlation of porosity to sediment composition, the effect of consolidation first was removed from the porosity data.

Using the isotopic stage boundaries determined by Kroon, Alexander, and Darling (this volume), together with the carbonate composition variation determined by Kroon, Alexander, and Thompson (this volume) and the index porosities measured on board the ship, we calculated the mass accumulation rate over the last 300 k.y. at Site 819 for total sediment and for the carbonate component of the sediment.

\section{SEDIMENT CONSOLIDATION}

The first-order trend of porosity with depth at Sites 819 through 821 can be described by sediment gravitational compaction or loss of porosity with depth, which is directly proportional to the in-situ effective lithostatic stress. The process whereby sediment pore fluid is removed and porosity reduced is termed consolidation, which was originally described by Terzaghi (1943). The rate at which the process of consolidation occurs is governed by the permeability of the sediment and the distance to a drainage path, in this case, the sediment/ water interface. Given enough time and a drainage path, sediment will 
consolidate as a function of effective pressure or as a function of depth below seafloor. This function of porosity reduction with depth (1) has been approximated as an exponential (Athy, 1930), (2) has been empirically determined from DSDP and ODP data (e.g., Brückmann, 1989), and (3) has been determined directly from the results of one-dimensional consolidation tests. In this study, we determine the porosity-depth function from consolidation test results.

The consolidation of a sediment can be reproduced in the laboratory. Essentially, the consolidation test measures the change in volume of a sample over a series of increasing stresses. The decrease in void ratio is calculated from the change in volume. The change in void ratio with respect to the effective stress plotted on a log scale provides the basic output of a consolidation test. The plot, otherwise known as a consolidation curve is used to determine the pre-consolidation pressure $P C^{\prime}$ (Fig. 1). The beginning of the curve ( $a$ to $b$ ) represents reloading of the sample. Little change in the void ratio was observed, because the sediment had already experienced this load. The straight line portion of the curve ( $c$ to $d$ ) is called the virgin compression curve. This curve results from the application of loads greater than those previously experienced by the sediment. The slope of the virgin compression curve $(\mathrm{Cc})$ is the reduction of void ratio as a function of effective pressure; it defines the porosity-depth function for the sediment tested. The curved part ( $b$ to $c)$ is the transition between reloading and new loads. The maximum curvature of the transition curve defines the position of the pre-consolidation pressure or the maximum past stress. The overconsolidation ratio is used to infer the state of the sample stress history. The OCR is defined as the ratio of pre-consolidation stress to existing effective vertical overburden. If $\mathrm{OCR}=1$, the sample has been normally consolidated. An OCR $>1$ indicates an overconsolidated sample and an OCR $<1$ indicates an underconsolidated sample. A normally consolidated sediment is one that has never been subjected to an effective pressure greater than the existing overburden pressure. An overconsolidated soil has been subjected to an effective pressure greater than the existing overburden pressure. An underconsolidated soil is not completely consolidated under the existing overburden pressure (ASTM, 1985).

Seven one-dimensional consolidation tests were completed on whole-round samples collected from Sites 819 through 821 (Table 1 and Fig. 2). Two tests were completed at Site 819 on samples from the deepest part of the hole, in lithologic Unit V. In lithologic Unit I, two tests were completed from Site 820 and three tests from Site 821 ,

Consolidation test results range from slightly overconsolidated behavior to extremely underconsolidated behavior. Samples from Site 819 and Subunit ID, Site 821 are underconsolidated with yield stresses of less than the overburden stress. Excess pore pressures likely exist locally at these sites. This underconsolidation or excess pore fluid pressure is likely the result of high sedimentation rates. At Site 820 , the stress history has been interpreted as overconsolidated in the upper $20 \mathrm{mbsf}$, which suggests that sediment has recently been removed either by mass wasting or by erosion. Given the geographic position of this site at a slope break, it is likely that removal of overburden occurred as a result of shallow sediment slumping. An estimate of the minimum amount of sediment removed, based on an average buoyant unit weight in Unit I, Site 820 is between 15 to 25 $\mathrm{m}$. Subunit IC (Site 821) has been interpreted as normally consolidated. Underconsolidated sediment in Subunit ID underlies this unit, suggesting a major change in depositional environments between these two subunits.

The slopes of the virgin compression curves $(C c)$ were determined for each test (Table 1). These indexes were used at each site to develop porosity-depth functions. Based on the composition of the lithologic units, we assumed $C c$ values for all of the lithologies at each site. Values of $C c$ were assumed for three lithotypes: clayey silt dominated sediment, chalk/carbonate dominated sediment, and dolomitic-dominated sediment (Table 1). Values of $C c$ were assigned to lithologies where consolidation samples were not taken, based on the dominant sediment type in each lithology (Table 2).

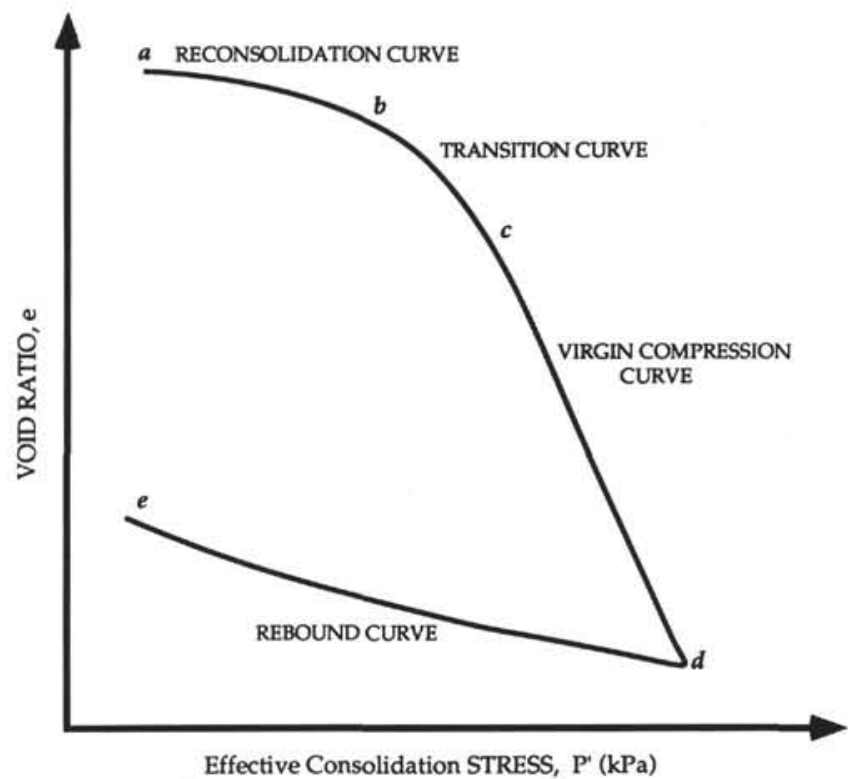

Figure 1. Generalized one-dimensional consolidation test. The beginning of the curve ( $a$ to $b$ ) represents reloading of the sample. The straight line portion of the curve ( $c$ to $d$ ) is called the virgin compression curve. It results from the application of loads greater than those previously experienced by the sediment. The slope of the virgin compression curve $(C c)$ is the reduction of void ratio as a function of effective pressure, it defines the porosity-depth function for the sediment tested. The curved part $(b$ to $c$ ) is the transition between reloading and new loads. The maximum curvature of the transition curve defines the position of the preconsolidation pressure or the maximum past stress.

In addition to interpreted stress history, the consolidation test results were used to estimate the elastic rebound of cores collected at Sites 819 through 821 . During consolidation test unloading, samples rebound elastically, thus mimicking the sediment behavior during coring where the sample undergoes unloading of the effective overburden stress. Elastic rebound $\left(C_{r}\right)$ from samples tested in this study can be grouped into three different elastic ranges (Table 1). Unit I and Subunit IC (Sites 820 and 821 , respectively) have an elastic rebound of $4 \% e / \log P_{o}^{\prime}$; Subunit ID (Site 821) has the highest elastic rebound $(10 \%-11 \%)$, and Unit V (Site 819$)$ has an elastic rebound of $7 \%$. The index porosity data have been corrected at each site by applying a composite rebound correction. $\mathrm{C}_{r}$ was applied to porosity data from the entire site by assigning appropriate values to each lithology (Table 2 ) in the same manner described for $C c$. The data were rebound corrected by applying the following equations:

$$
\begin{gathered}
e_{c}=e_{m}-\left(C_{r} \cdot \log _{10} P_{o}^{\prime}\right) \\
n_{c}=\frac{e_{c}}{1+e_{c}}
\end{gathered}
$$

where $e$ is void ratio and $n$ is porosity. Subscripts $c$ and $m$ refer to corrected and measured values, respectively. $P_{o}^{\prime}$ is effective overburden stress.

The elastic rebound was first applied to the measured void ratio values $\left(e_{m}\right)$ using Equation 2 and then rebound-corrected porosity was calculated using the phase relationship (Eq. 3). Figure 3 is a summary of porosity plotted vs. depth, showing the measured values and the rebound-corrected values at each site. These data are compared to the porosity-vs.-depth functions determined from the measured $C c$ values. The normally consolidated porosity-vs.-depth functions, when compared with rebound-corrected porosity, suggest that Site 821 is dominated by underconsolidation in the upper $200 \mathrm{mbsf}$, Site 820 is generally overconsolidated throughout, and Site 819 is normal to overcon- 
Table 1. Summary of one-dimensional consolidation test results.

\begin{tabular}{llrlrllll}
\hline $\begin{array}{c}\text { Core, } \\
\text { section }\end{array}$ & $\begin{array}{c}\text { Lithologic } \\
\text { unit/lithology }\end{array}$ & $\begin{array}{c}\text { Depth } \\
(\mathrm{mbsf})\end{array}$ & $\begin{array}{c}P^{\prime} \\
(\mathrm{kPa})\end{array}$ & $\begin{array}{c}\mathrm{Po}^{\prime} \\
(\mathrm{kPa})\end{array}$ & $\mathrm{OCR}$ & $\mathrm{Cr}$ & $\mathrm{Cc}$ & Stress history \\
\hline 819A-39X-2 & V/chalk & 344.0 & 158 & 3216 & 0.05 & 7 & 0.35 & Underconsolidated \\
819A-39X-3 & V/chalk & 345.0 & 126 & 3231 & 0.04 & 7 & 0.32 & Underconsolidated \\
820B-1H-5 & I/clayey silt & 6.6 & 177 & 43 & 4.12 & 4 & 0.38 & Overconsolidated \\
820B-2H-6 & I/clayey silt & 15.8 & 200 & 109 & 1.83 & 4 & 0.43 & Overconsolidated \\
821A-5H-6 & IC/clayey silt & 41.4 & 355 & 332 & 1.07 & 4 & 0.38 & Normally consolidated \\
821A-6H-6 & ID/dolomitic & 50.8 & 158 & 416 & 0.38 & 11 & 0.47 & Underconsolidated \\
821A-7H-6 & ID/dolomitic & 60.4 & 100 & 499 & 0.20 & 10 & 0.40 & Underconsolidated \\
\hline
\end{tabular}

Note: $P_{\mathrm{c}}{ }^{\prime}=$ effective pre-consolidation pressure, $P O^{\prime}=$ effective overburden stress, $\mathrm{OCR}=$ overconsolidation ratio, $C r=$ coefficient of elastic rebound, and $C c=$ coefficient of compresibility.

Table 2. Assigned values of the coefficient of compressibility and the rebound coefficient for all lithologies at each of the study sites.

\begin{tabular}{llrl}
\cline { 2 - 4 } Site & $\begin{array}{c}\text { Lithologic } \\
\text { unit }\end{array}$ & $\begin{array}{c}C r \\
(\%)\end{array}$ & $C c$ \\
\hline & & 4 & 0.40 \\
819 & I & 7 & 0.33 \\
819 & II & 4 & 0.40 \\
819 & III & 7 & 0.33 \\
819 & IV & 7 & 0.33 \\
819 & V & 4 & 0.40 \\
820 & I & 7 & 0.33 \\
820 & II & 7 & 0.33 \\
820 & III & 4 & 0.40 \\
821 & IA-IC & 10 & 0.43 \\
821 & ID & 4 & 0.40 \\
821 & IE-IG & 7 & 0.33 \\
821 & II & 7 & 0.33 \\
821 & III & 7 & 0.33 \\
821 & IV & 10 & 0.43 \\
821 & V & 10 \\
\hline
\end{tabular}

Note: $C c=$ coefficient of compressibility; $C r=$ rebound coefficient.

solidated. The interpretations of the discrete consolidation samples (Table 1) are consistent with these trends. Although both consolidation samples from Site 819 are interpreted as underconsolidated, the rebound-corrected porosity data at these test depths also are underconsolidated locally. All of the other consolidation test results are locally consistent with the rebound-corrected porosity and the estimated normally consolidated porosity-vs.-depth functions.

The differences in the general stress history interpreted from comparison of rebound-corrected porosity to normally consolidated porosity-vs.-depth functions among the three sites can be explained by the physiographic location of each site and the biostratigraphic results. Sites 819 through 821 are located along a slope transect, with Site 819 located in the deepest water of the three sites. Sedimentation rates, interpreted from biostratigraphic results (Shipboard Science Party, 1991) are high for all lithologies at these sites, greater than $10 \mathrm{~cm} / \mathrm{k} . \mathrm{y}$. It is likely that the high sedimentation rates result initially in underconsolidation. However, another process, mass wasting, influences this initial depositional stress history. As mass wasting occurs, the stress history for the underconsolidated sediments shifts to either normally consolidated conditions or slightly overconsolidated conditions. Based on this interpretation, it is likely that Site 821 has been little influenced by mass wasting, and sediment stress histories at Sites 819 and 820 have been altered by removal of overburden from sediment slides and slumps. Sedimentological evidence of slump events were interpreted by the Shipboard Science Party (1991) at Site 819.

At each of the three sites, the stress history of the oldest sediment recovered is generally overconsolidated, with some local exceptions (344-345 mbsf at Site 819; Table 1). Given that the upper sediment units of Site 821 are underconsolidated, the overconsolidation at depth may either mark a large regional erosional event or the deeper sediments may have been overconsolidated by diagenetic processes (e.g., dolomitization).

Our interpretation of the stress history at these sites is based on assumptions about the elastic behavior and compressibility of lithologies; these have not been tested in the laboratory. Additional wholeround samples were collected at these sites during Leg 133 and, as consolidation tests are completed, the elastic rebound curves and porosity-depth functions will be improved.

\section{CORRELATION}

As shown in the site chapters in the Initial Reports volume of the Proceedings of the Ocean Drilling Program for Leg 133, graphical comparisons between porosity and other variables (such as $\mathrm{CaCO}_{3}$ content) suggested locally strong correlations between porosity and other variables. These graphical correlations suggested local causal relationships between porosity and lithological factors.

In an attempt to establish more generally the extent of lithologic controls on porosity, we calculated correlation coefficients among various combinations of observed index porosity, inferred porosity from the GRAPE and wireline density observations, $\mathrm{CaCO}_{3}$ content, sand vs. mud content, and magnetic susceptibility. In this case, mud was defined as all grains having diameters $<64 \mu \mathrm{m}$. A high degree of correlation suggests that it is worth considering a causal relationship between some aspect of lithology and porosity. Several complications arise when trying to apply this concept in the present situation. One problem is a sampling problem-we do not necessarily have observations of the parameters of interest at the same depth $z$. Another problem is a unit of measure problem - two curves $X(z)$ and $Y(z)$ may have apparently different shapes because the units of measurement are different. A third problem is a multiple control problem-some variables, most notably porosity, have variations with depth that may be result from several independent variables. In the case of porosity, we know that generally porosity decreases with depth because of compaction and dewatering as a result of the overlying lithostatic load (Shipboard Science Party, 1991). If one is searching for the effects of lithology on porosity, one would want to remove the porosity trend that is a function of overburden.

Before correlating porosity with any other variable, we calculated a best-fit exponential curve that described the porosity at each site. We subtracted this best-fit curve from our observations so that we were dealing with a residual porosity. The sampling problem was handled by combining data sets with a search for the data point in data set $X$, which was closest to a given depth in data set $Y$. An arbitrary limit of $5 \mathrm{~cm}$ was set, in most cases, so that the search would not return a value if no value in $X$ was within $5 \mathrm{~cm}$ of the given value in $Y$. To eliminate the problem of units, we normalized each set of observations, $X(z)$, such that its mean, $X$, became zero and its standard deviation, $s$, became 1 :

$$
X_{n}(z)=\frac{(X(z)-\bar{X})}{s}=\text { normalized } X(z) .
$$



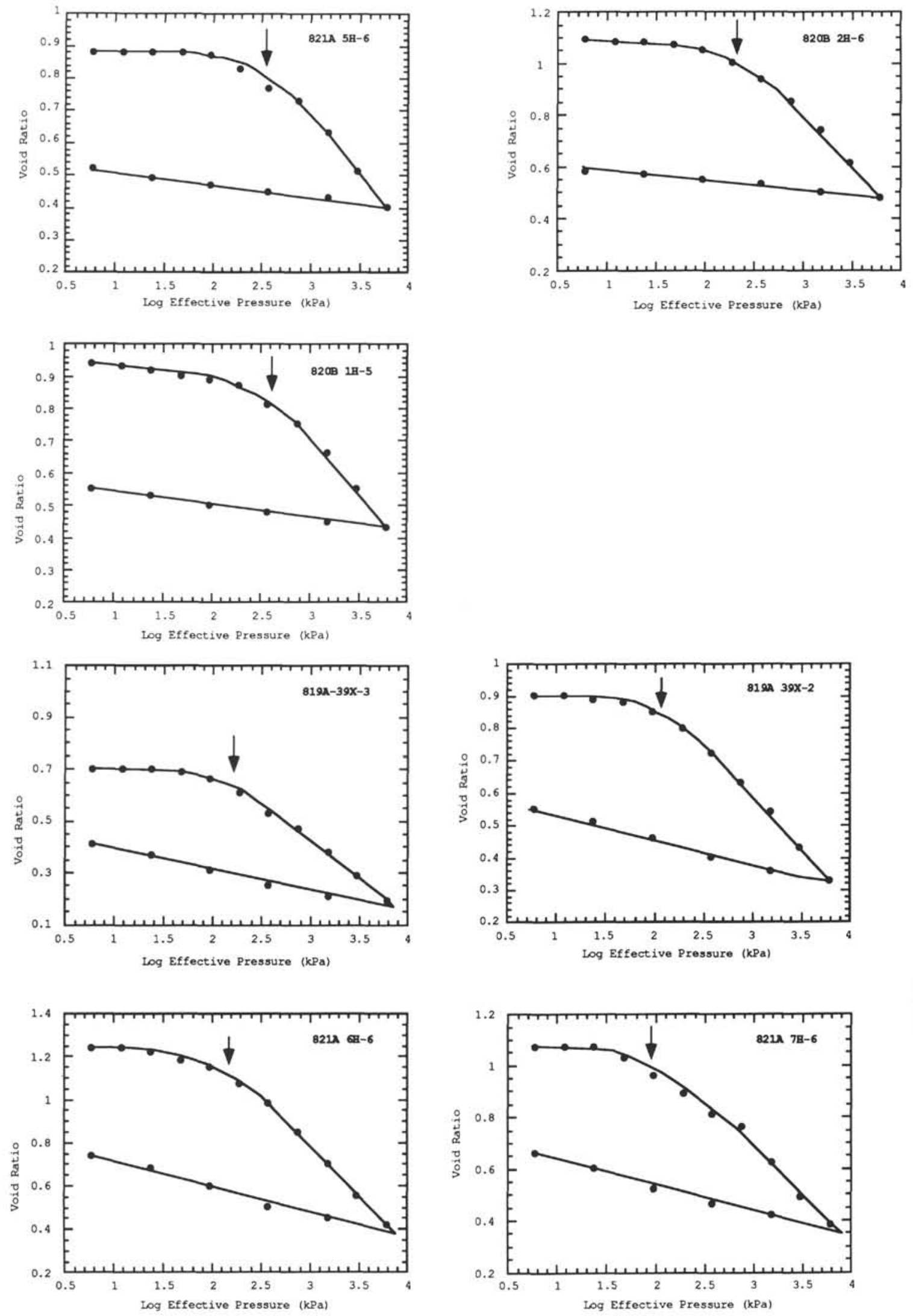

Figure 2. One-dimensional consolidation tests on whole-round samples from Sites 819 through 821 . The vertical arrow in each plot indicates the preconsolidation pressure $P_{c}{ }^{\prime}$. 

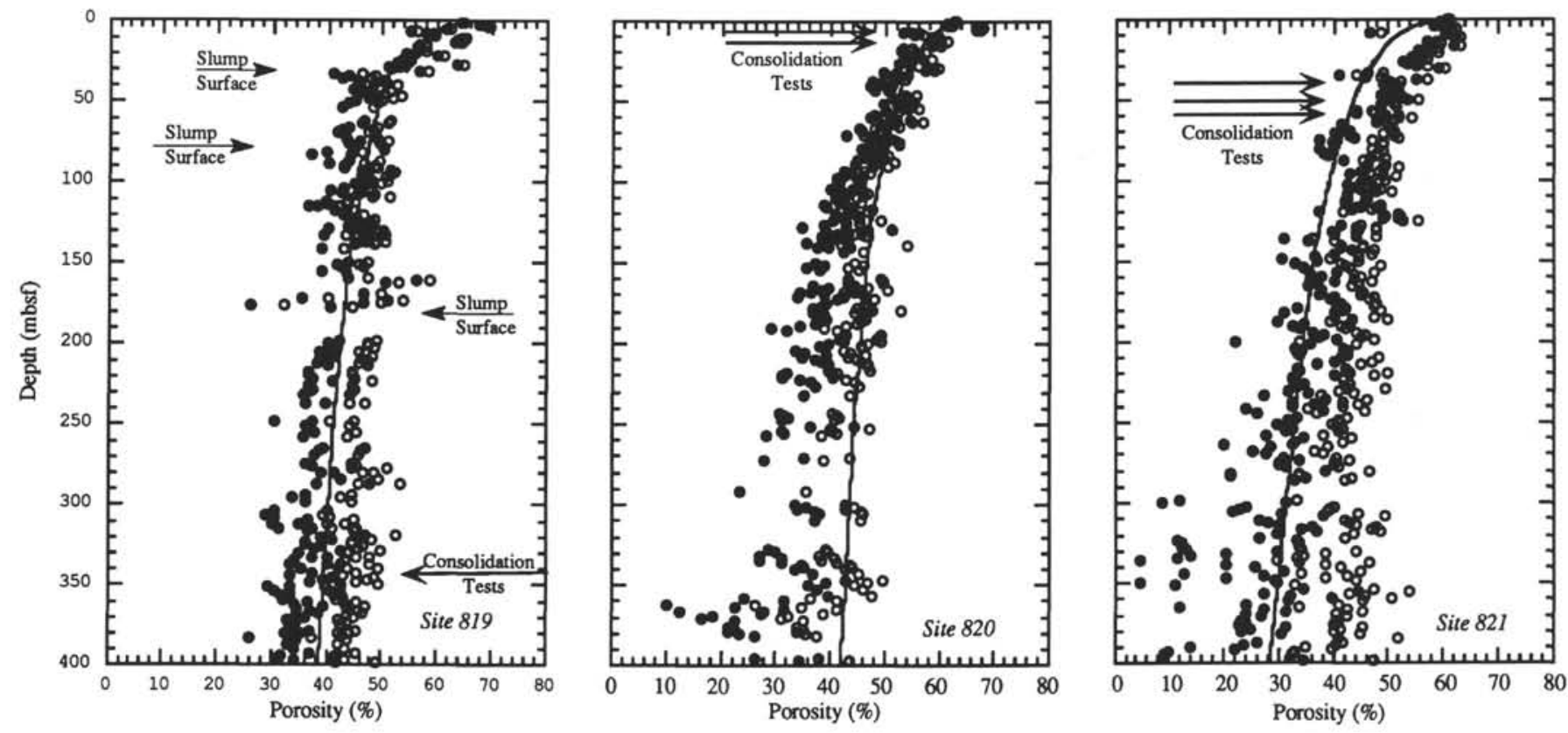

Figure 3. Porosity plotted as a function of depth below seafloor for Sites 819 through 821 . Open circles represent shipboard-measured data, solid circles represent data corrected for elastic rebound, and solid curve indicates predicted normally consolidated porosity-vs.-depth function based on the slope of the virgin compression curve $\left(C_{c}\right)$ and the observed initial void ratio from the first core at each site. For Site 819, we have indicated the depth of slump surfaces reported by the Shipboard Science Party (1991).

This normalization was performed after combining two data sets and has the effect of preserving the shapes of the curves, while equalizing the amplitudes and removing any bias due to arbitrary measurement reference levels. Finally, a correlation coefficient was calculated. Because of the time-consuming nature of determining index porosity, we do not have many measurements of index porosity; the result of combining this sparse data set with another sparsely sampled data set might have led to few data points that lie within 5 $\mathrm{cm}$ of each other. In an attempt to avoid this problem, we derived porosity from the much more numerous measurements of density from cores using the GRAPE on the multisensor track (MST) and from wireline logs (see description in Jarrard, Jackson, et al., this volume). We correlated both index porosity and this derived porosity with the independent measurements of lithology. The results for Site 819 for the depth range 0 to $400 \mathrm{~m}$ are presented in Table 3 .

Making the usual statistical assumption of independent data, one can calculate the confidence limits at which a given correlation coefficient is significant. This level of significance depends upon the number of data samples. In Table 3, we have tabulated the correlation coefficient for a $99 \%$ confidence limit for varying sample sizes. Comparison of this $99 \%$ confidence limit with the observed correlation is our arbitrary criteria for establishing whether an observed correlation is significant.

One problem with the above correlations is that when correlating variables over the entire length of the hole, we are mixing together parts of the section where relationships among variables may be different.

A large negative correlation exists between $\% \mathrm{CaCO}_{3}$ and porosity. A similar inverse relationship between porosity and $\% \mathrm{CaCO}_{3}$ was found by Nobes et al. (1991) in sediments from the East Georgia Basin and Meteor Rise in the far South Atlantic Ocean. Young, clay-rich (terrigenous) sediments tend to exhibit high porosity (Silva et al., 1983), which is seen in this inverse relationship between $\mathrm{CaCO}_{3}$ and porosity. In addition, diagenetic processes (carbonate cementation) may tend to decrease porosity, enhancing the contrast in porosity between clay-rich and carbonate-rich sediment sequences. A less pronounced correlation was found between porosity and particle size.
Little or no correlation was found between magnetic susceptibility and porosity. In general, magnetic susceptibility correlates with porosity or bulk density to the first order because the susceptibility is higher where the magnetic minerals are denser (high density) and susceptibility is lower where the magnetic minerals are less dense (lower density). However, the correlation coefficients in Table 3 were calculated after removing the first-order porosity-vs.-depth function; thus, no first-order correlation should be expected.

\section{MASS ACCUMULATION RATES}

Given detailed sedimentation rates, porosities, grain densities, and weight percent $\mathrm{CaCO}_{3}$, it is possible to calculate detailed mass accumulation rates for total-sediment, $\mathrm{CaCO}_{3}$, and non- $\mathrm{CaCO}_{3}$ fluxes. We have done this for the top $30 \mathrm{~m}$ at Site 819, where oxygen isotope measurements (see Kroon, Alexander, and Darling, this volume) permitted our determining detailed sedimentation rates, and we have the requisite measures of percent $\mathrm{CaCO}_{3}$ (Kroon, Alexander, and Thompson, this volume), porosity, and grain density.

The results are shown in the accompanying Figure 4 . The picture that emerges is one of a fairly low total mass accumulation rate from 240 to 100 k.y. preceded by a somewhat elevated rate between the hiatus at 300 and 250 k.y. From 100 k.y. to the present, there has been a steadily increasing total mass accumulation rate from about 10 $\mathrm{g} / \mathrm{cm}^{2} / \mathrm{k}$.y. to a present value of about $50 \mathrm{~g} / \mathrm{cm}^{2} / \mathrm{k}$.y. Similarly, the $\mathrm{CaCO}_{3}$ and noncalcareous mass accumulation rates were low and steady from 240 to 100 k.y. and have risen since; however, during the last $50 \mathrm{k} . \mathrm{y}$., large perturbations have occurred in the noncalcareous mass flux, with compensating perturbations in the $\mathrm{CaCO}_{3}$ flux. We see no indication of the $100 \mathrm{k} . y$. cyclicity that dominates the oxygenisotope, and presumably sea-level, history of this period.

The history of mass accumulation rates at Site 819 over the last 300 k.y. may reflect the development of the reef surrounding Grafton Passage over this time period. If during this time period the reef increasingly became a barrier to the seaward transport of terrigenous sediments (except through Grafton Passage) and Grafton Passage 


\section{J. LADD ET AL.}

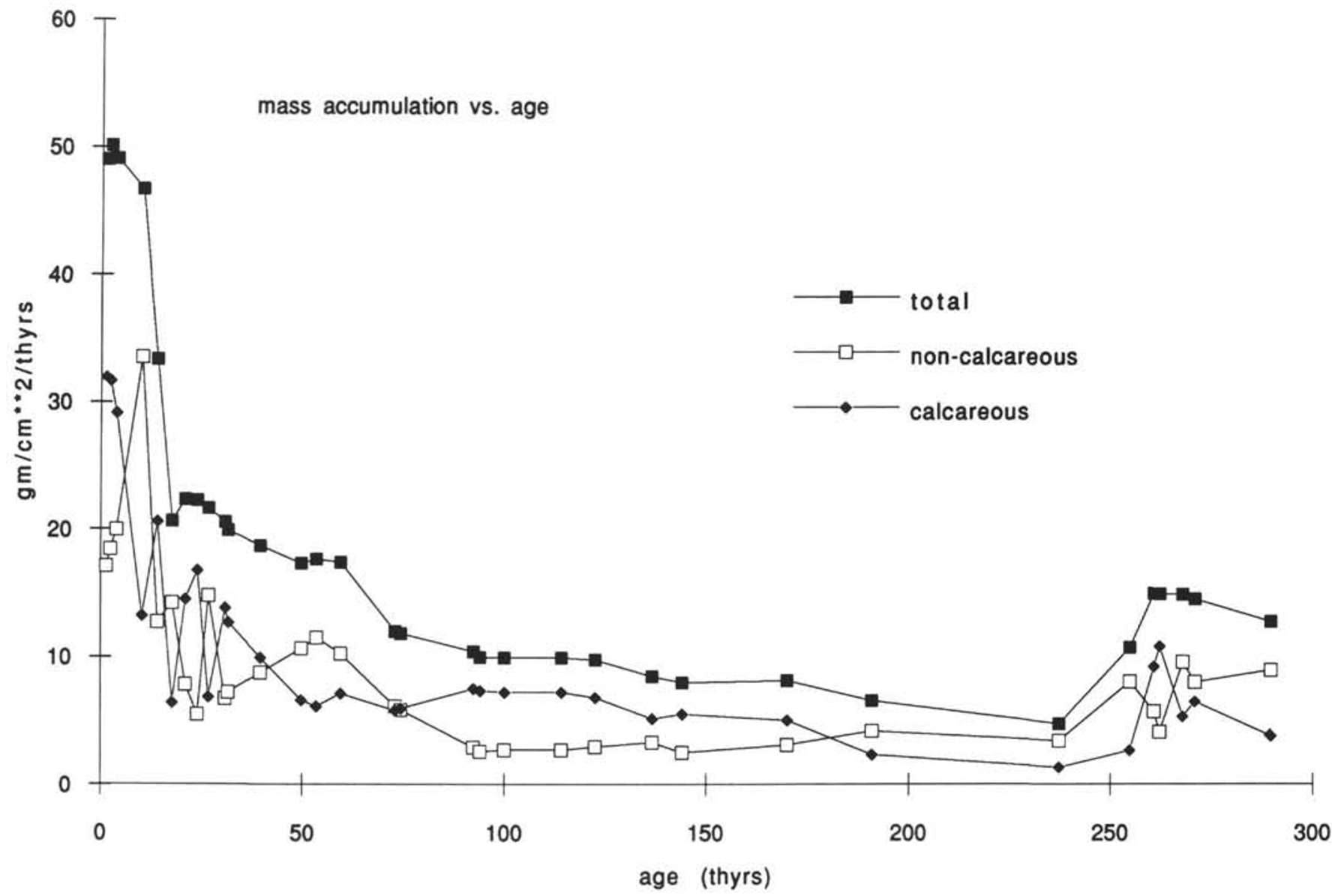

Figure 4. Mass accumulation rates vs. age for the upper $30 \mathrm{~m}$ at Site 819 . These rates have been calculated from the bulk density vs. depth measurements (Shipboard Science Party, 1991), isotopic stage boundaries (Kroon, Alexander, and Darling, this volume) and carbonate composition data (Kroon, Alexander, and Thompson, this volume).

Table 3. Correlation of normalized porosity with normalized susceptibility, normalized grain size, and normalized carbonate content.

\begin{tabular}{lrrrr}
\hline & $\begin{array}{r}\text { Observed } \\
R\end{array}$ & $\begin{array}{c}\text { No. of } \\
\text { samples }\end{array}$ & $R$ at & $\begin{array}{c}\text { 99\% confidence on no. of } \\
\text { samples }\end{array}$ \\
\hline Normalized index porosity correlated with normalized susceptibility & -0.024 & 198 & 0.195 & Correlation not significant \\
Normalized \%mud & 0.112 & 93 & 0.267 & Correlation not significant \\
Normalized \% CaCO & -0.214 & 200 & 0.194 & Correlation significant \\
Inferred porsoity correlated with normalized susceptibility & 0.139 & 1519 & 0.115 & Correlation significant \\
Normalized \%mud & 0.345 & 427 & 0.129 & Correlation significant \\
Normalized \% $\mathrm{CaCO}_{3}$ & -0.461 & 243 & 0.167 & Correlation significant \\
\hline
\end{tabular}

Note: Prior to normalization, the first-order effect of consolidation on porosity was removed.

became a principal funnel of sediments, then the observed pattern of mass accumulation at Site 819 might be explained. One needs to make similar calculations at Sites 820 and 821 .

\section{CONCLUSIONS}

1. Most of the sediments at Sites 819 through 821 are underconsolidated, likely the result of high sedimentation rates. Normally consolidated sediments appear at intervals of low sedimentation rate at Site 820. Overconsolidation occurs in the shallowest unit of Site 820 , suggesting recent mass wasting, and at the deepest interval, which might define an older erosional surface.

2. At Site 819 for the depth range 0 to $400 \mathrm{~m}$, porosity is correlated with percentage of mud and inversely proportional to carbonate content.
3. Mass accumulation rates in the upper $30 \mathrm{~m}$ above a major hiatus at Site 819 are fairly constant from 240 to 100 k.y. following a 50-k.y. period of slightly higher accumulation rates. The mass accumulation rate increases steadily from $100 \cdot$ k.y. to the present.

\section{REFERENCES $*$}

ASTM, 1985. Standard terms and symbols relating to soil and rock (Standard D653-85). Annual Book of ASTM Standards for Soil and Rock: Building Stones (Vol. 04.08): Philadelphia (Am. Soc. Testing Materials).

\footnotetext{
- Abbreviations for names of organizations and publication titles in ODP reference lists follow the style given in Chemical Abstracts Service Source Index (published by American Chemical Society).
} 
Athy, L.F., 1930. Density, porosity and compaction of sedimentary rocks. AAPG Bull., 14:1-24.

Brückmann, W., 1989. Typische Kompakationsmuster mariner Sedimente und ihre Modifikation in einem rezenten Akkretionskeil (Barbados Ridge). Beitr. Geol. Inst. Univ. Tübingen, Rh. A, 5:1-135.

Nobes, D.C., Mienert, J., and Dirksen, G.J., 1991. Lithologic control of physical-property interrelationships. In Ciesielski, P.F., Kristoffersen, Y, et al., Proc. ODP, Sci. Results, 114: College Station, TX (Ocean Drilling Program), 657-669.

Shipboard Scientific Party, 1991a. Site 819. In Davies, P.J., McKenzie, J.A., Palmer-Julson, A., et al., Proc. ODP, Init. Repts., 133 (Pt. 1): College Station, TX (Ocean Drilling Program), 451-508.

1991b. Site 820. In Davies, P.J., McKenzie, J.A., Palmer-Julson, A., et al., Proc. ODP, Init. Repts., 133 (Pt. 1): College Station, TX (Ocean Drilling Program), 509-568. 1991c. Site 821. In Davies, P.J., McKenzie, J.A., Palmer-Julson, A., et al., Proc. ODP, Init. Repts., 133 (Pt. 1): College Station, TX (Ocean Drilling Program), 569-614.

Silva, A., Moran, K., and Akers, S.A., 1983. Stress-strain-time behavior of deep sea clays. Can. Geotech. J., 20:517-531.

Taylor, D.W., 1948. One-Dimensional Consolidation: Fundamentals of Soil Mechanics: New York (Wiley and Sons).

Terzaghi, K., 1943. Theoretical Soil Mechanics: New York (Wiley).

Date of initial receipt : 15 April 1992

Date of acceptance : 23 March 1993

Ms 133SR-269 